International Journal of Advanced Studies in Humanities and Social Science (IJASHSS)

Available online at http://www.ijashss.com

Volume 7, Issue 4 (2018) pp. 426-436

Original Article

\title{
Pars Sea: Maritime Connection between Iran and Indian Subcontinent
}

\author{
Ali Ahmadalizadeh ${ }^{*}$, Nader Karimian Sardashti2 \\ ${ }^{1}$ Research Organization and Curriculum Development, Ministry of Education, Tehran, Iran \\ ${ }^{2}$ The Faculty of Tourism, Handicraft, Cultural Heritage of Search in statute, Tehran, Iran \\ *Corresponding Author E-mail: dr.alizadeh@yahoo.com
}

Received: 24 October 2018, Revised: 05 December 2018, Accepted: 20 December 2018

\begin{abstract}
Pars Sea has witnessed critical events that have affected the history of Iran, some positively and some negatively. Babylonians and Assyrians called Pars Sea as the lower sea (in the direction of Mesopotamia downstream). This sea was called Pars Sea on the inscription from Darius Ierafound along the connecting channel between Nile River and Suez Canal. The naming of Pars Sea stemmed from being the connecting waterway to Pars Gulf inland or Iran. Achaemenid Dynasty who ruled Pars extended its reign from Mediterranean on the west to Indian Sea, Send River, and Pamir Plateau on the East. The north part of their territory included the area from Black Sea to Lake Baikal including Khawrezm and Khazar on the North. Neighborly relation with India strengthened the economic, political, and cultural relations of the two countries. Pars Sea served as the main waterway between East and west. This waterway was sometime referred as Silk Waterway. This article is a discussion of Iran-India maritime relations through Pars Sea.
\end{abstract}

Keywords: Pars Sea, Indian Subcontinent, Persian Gulf, Iran, Pre-Islamic Era, Silk Waterway, Maritime.

\section{Introduction}

Jawaharlal Nehru, the first Indian Prime Minister, wrote in his book, "Among many nations who were connected to India and had cultural influence, Iranians maintained the longest continual relation through Silk Waterway. The relationship between Iran and India dates back to pre-Indian-Arian civilization. Indian and Arian nations shared common roots with ancient Iranians who chose different geographical areas for their settlement. The two nations rose from a single race. They had similar religions and languages. Vedic religion of India and Zoroaster religion of Iran shared common beliefs. Vedic Sanskrit language and Ancient Pahlavi language, Avesta, were similar in many respects" (Nehru, 1977).

The beginning of Iran-India relation is not clear in the long history of the two ancient civilizations. However, the diplomatic relationship between the two countries started as soon as governments were formed in these two countries and politics governed the relationship between two countries. As political and cultural 
relations between Iran and India developed, so did the economic relation.

The history of political-economic relation between Iran and India is longer than 2500 years. Iranians established relationships with other nations and governments starting from $1000 \mathrm{BC}$. These relationships developed into political-cultural-economic ties. Ancient Iran was connected to Egypt and Greece through Mediterranean Sea. She was also connected to Far East countries, like India, through the caravan roads that ended in China on the north. Therefore, Iran played an active role in international trading and cultural transactions at that time via sea and land.

\section{Research Significance}

Iran and India are two countries with long history and very established political governments. These two countries formed two ancient civilizations sharing common heritage and taking influence from each other. Identification of the bilateral influences is important in a study of political-cultural-economic-trading

relations between the two countries. Pars Sea served as the connecting waterway between the two nations and was instrumental in facilitating their relationship. This study is a detailed examination of the significance of Pars Sea (Persian Gulf) referred here as Silk Waterway.

\section{Research Objective}

The main objective of this study is to provide a pre-Islamic historical account of political-economic-trading relations between Iran and India through Pars Sea. Pars Sea was the connecting waterway which facilitated trade of goods as well as political and cultural exchange.

\section{Research Question and Hypothesis}

The main question in this article is what facilitated the historical relationships between Iran and India through Pars Sea. The ship building industry played an important role in facilitating the relationship. This relationship, in turn, was instrumental in the development of ship building industry. This paper attempts to describe the types of commercial, political, and cultural relations that existed between the two countries.

\section{Research Methodology}

This study was a library research. The data used in this study was taken from many literature and library resources including ancient and historical texts, mostly from pre-Islamic era.

\section{Literature Review}

Books and articles written about Iran and India maritime relation are very rare. This study may be the first one about the role of Pars Sea in the relationship between Iran and Indian Subcontinent.

\section{History of Iran-India Relation}

History of Iran-India relation includes five historic periods.

\section{Pre-Achaemenid Era}

Pre-historic people who lived in Iran Plateau maintained relations with neighboring and far away nations. The silk people who lived near Kashan5000 years $\mathrm{BC}$ were from the same race as of Indians. Thus, they stayed in close contact with them.

About 4000 years BC, during a period called Vedic, Arian nations were either still living together or had just segregated into Iran and India, yet, they remembered their traditions. This period is named Vedic Era 
after Book of Veda as one of the oldest religious books. RigVeda is the oldest section of Book of Veda which dates back to 4000 years BC. Rig Veda mentioned an account Arian nation before they segregated to settle in Iran and India. Veda language and particularly, Rig Veda are similar to Avesta language.

Boghazkoiinscription found in 1907 in ancient capital of Hittians in Asia Minor, whose inscriptions dates back to 1400 to 1300 BC, mentioned a number of Vedic Gods including Indra, Varuna, Mitra, Venasattia (Nahid)as guarantors of the treaty between Hittie and Mitani, the two nations residing west of Iran plateau. What we can deduce from this inscription is that Arian nation of Iran and India had not separated yet in $1400 \mathrm{BC}$ and Vedic religion had extended far beyond Iran Plateau to reach Asia Minor (Mashkoor, 1976).

Dravidian was the most populated city of India before Arian nation invasion and settlement in India. This name is now referred to a group residing in south of India, Baluchistan, and Persian Gulf Shores. These people may be successors of Dravidian people (Mosahab, 1966).

Ethnological findings prove the ancient relationship between Iran and India before Arian tribes' migration to India and Iran Plateau. The findings show that the current language spoken by Brahui tribes, who reside in Baluchistan highlands and Persian Gulf seashore, is related to one of Dravidian dialects spoken south of India. This may indicate that Dravidian people withdrew from Iran to India and resided in south of Indian Subcontinent after Arian tribes invasion. Only one tribe remained in Baluchistan and also scantly throughout Persian Gulf Islands and Seashores who kept their language intact (AfsharYazdi, 1985).
Will Durant stated in his book, "Dravidian is the name of people and the name of their languages. Some people with brown skin and long head came to north and northwest of India at lEast one thousand years before Arians migrated to India. Dravidian languages are taken from their culture. It appears that Dravidians were the first people who formed a civilization in Send Valley. They had advanced social and political systems (Durant, 1986). Without any doubt, their migration to Iran has been through sea. That may explain why their successors still live on seashore.

Euphrates and Tigris Rivers were the two main waterways connecting east to west during Pre-Achaemenidae Era. These two rivers through Pars Sea served as the connecting waterway between India and Mediterranean Sea. During Chaldean King Nebuchadnezzar (604-561 BC) reign, Tredon Port on Persian Gulf was the intermediary trading port between India and Soor Port in Phoeniciain Mediterranean Sea - presently in Lebanon. Goods from India would be shipped to Tredon Port, and then they would go through Euphrates Valley to Syria. The goods would then be transported from Syria inland to Phoenicia and its ports.During Pre-Achaemenid era, this route was more important than the waterway through Red Sea and Nile River. Iranians preferred inland routes over waterways. They used Euphrates River as an irrigation channel and a defensive barrier. Iranians used India-Red Sea waterway for their trades. Trading ships could travel from India to countries along Mediterranean Sea after the canal between Red Sea and Mediterranean Sea started its operation (Eghtedari, 1965).

Trading ships could take one of the two routes to India. One way was to make calls at two busy ports on Oman Seashore by 
the name of Sohar and Muscat. The ships would then sail to KolemMeli (Ceylon) in south Malabar. This was the same route taken by ships destined to China. The other way was to make calls to Kish Island, Old Hormoz, and Tiz in Markan (Hoorani, 1969).

\section{Achaemenid Era}

Achaemenid Empire was established in 559 BC. They formed a strong centralized government throughout Iran which has recorded the oldest political relations with other nations. KuroshKabir, as the first ruler of Achaemenid, annexed most of states under Median Empire through negotiations and direct conflicts. Thus, Assyria, Armenia, Cappadocia, and mountains of Iran Plateau became part of Achaemenid Empire. During Kurosh reign, Achaemenid government made peace agreement with Greeks of Asia Minor, Kilikian, and Babylonian in 538 and 543546 BC (Mahmid, 1982).

DariushKabir conquered India and crossed Send River to annex India to his kingdom in 512 BC. Send and Punjab Provinces were among rich and wealthy parts of Indian. They paid their annual dues in gold to Iran and according to Herodotus. Iran sold the gold to Rome. Inland routes of Achaemenid period were used during the reign of Alexander and his successors, as known as Solookian kings. However, they were unable to utilize the vast maritime routes of the same period which covered east of Africa, Red Sea, Pars Sea, and all the way to Indian shores (Eghtedari, 1965).

Dariush dispatched discoverers and searchers, such as Silaksto India as part of his efforts to turn Iran into a maritime power. This initiation is rare in the history of civilizations. He encouraged the development of certain scientific fields such as astronomy due to their important rolein navigation. He established a university in Egypt as part of this effort. Later, wild hens and roosters from India were taken from Indian forests and transferred to countries along Mediterranean Sea. They became the local birds of the west (IIliff, 1953).

India-Iran relations during Achaemenid era influenced architecture and inscription in India. Ashoka (372-232 BC), the famous Buddhist king of India, built a palace in his capital, Pataliputra, fashioned after Dariush palaces. A hall with hundred columns fashioned after Achaemenidpalaces was found in the area in 1896. Another hall with eighty columns was discovered in 1912. The columns in this hall were single piece polished columns similar to columns found in Apadana Hall in TakhtJamshid. The architect of this historical site was influenced by Achaemenid palaces in TakhtJamshid.

Ashoka established the tradition of inscription for the first time in India in imitation of inscriptions made during Dariush and other Achaemenid kings. The remains of Ashoka inscriptions still exist in Gaya Mountains in Indian Bihar State. There are many works of arts from Ashoka time that show the influence of Iran arts and architecture in India Subcontinent. They are the evidences of relationship between the two countries, especially maritime, during Dariush reign (Mashkoor, 1976).

Persian Gulf islands maintained close ties with India Subcontinent during Achaemenid era. Kish Island was one of the main centers of pearl fishery in Persian Gulf. It was the pearl trading port between Mesopotamia and India. Yaqut al-Hamawi wrote in seventh century $\mathrm{AH}$ about the marine trade between India and Persian Gulf region where ships would make 
frequent calls to Kish Island (Yaqut alHamawi, 1966).

The trade between Kish Island and India was mentioned in a story by Sheikh Saadi when he met a trader who said he had funds in India and planned to take Indian steel to Halab- or Aleppo, Syria (Hamidi, 1990).

Another document attesting to the old relationship between Persian Gulf Islands and India was mentioned in a story by Sir William Ouseley about the naming of Kish Island. According to a hand-written Farsi book, the naming of Kish Island came about after a son of a poor widower by the name of Ghayse boarded a ship to India with his cat in an attempt to escape poverty. It was a time when India was infested by mice growth. The number of mice has increased so much that they would freely feed on King's meal. Several servants had to stand guard to disperse mice at king's meal time. Ghayse heard about the problem and brought his cat to chase the mice away. The mice disappeared from the scene in a short period and Indian King gave him valuable rewards. Ghayse returned to Sirafand took his mother and brothers with him. This Island is called Kish which is Farsi name for Ghayse after this incidence (Wilson, 1969).

\section{Solookian Era}

The eastern territory under Alexander rule included Iran and certain parts of India. The area was kept in Solookian era (330312 BC) which included Alexander of Macedonia and his successors. The area was divided into 14 Satrapies. Persian Gulf Islands and Pars Country was one Satrapy (Diaconoff, 1972). Solookians ruled 25 to 28 Satrapies (312-129 BC). A Satrapy was divided into Aparkhies. An Aparkhy was divided into Hyparkhies. Satrap was the territory along Eritrea, an area that included Persian Gulf, Mocran Sea, and Eritrea Sea according to old maps (Gutschmidt, 1965).

Maurya Empire was established by Chandragupta in north of India one and a half century after withdrawal of Alexander from India. It had two states, namely, Alakozai and Kedrozai (old names of Afghanistan and Baluchistan). Maurya Empire became neighbor to Solkidian Empire. The neighborly relation between these two countries promoted marine traveling and trades to northwest of India via routes to Send River Valley (Illiff, 1953). Iran cultural and architecture influence can be observed throughout Chandragupta territory (Vilrus, quoted in Pigat, V. 4, p. 85).

Further Iran influence on India is evident from fifth century BC. For example, Young and Miller reported that Indian holed silver coins were modeled after Iranian coins. Kharosthi Alphabet found in Taxila was taken from Iranian Arami Alphabet of Zoroastrian religion. Among artifacts found in Taxila are two valuable jewelries that earlier thought that they were Greek but later they were recognized as belonging to Achaemenidae era (Ancient India Book, V. 1, p. 32; ibid, V. 4, p. 94).

\section{Parthian Era}

MehrdadII (132-78 BC) marked the revival of political relations between Iran and east and west. He benefited from the strategic position of his territory as the midway stop on the trading routes to India and China, mainly in cause of Silk Road. The Parthians provided direct security over trading and military routes including Silk Road, Silk Maritime, Spice Road, and Pearl Road.

Pars territory remained independent during Parthian Empire. Mayer wrote in reference to Pripolus: "Pars never became 
a part of Parthian Empire, though Pars Kings had accepted their superiority." (Pripolus, 1927; Strabon, 1866). Pars territory includedKarmania shores (Mocran State in Baluchistan) and the shoreline along north of Persian Gulf opposite Suadi Arabia in Sea of Oman. IsidoreKharaschmentionedArdeshir as one of Pars Kings. Other kings whose names are stamped on coins areDariush, Nersi, Tirdad, Manoochehr, etc. (Mimir, V. 2, p. 452).

The territory covering Pars, Karmania, southern shore of Persian Gulf, and current Oman was under Iranian rule at the time of Pripolus. Governing this vast area was only possible with marine power. Iranians who lived in Karmania most likely had sea going fleet even before Pripolus time (Hadi Hassan, 1976, p. 9). There are other documents that prove the marine capabilities of Iranians who lived in Karmania. Capitan EimarehKermani, BozorgIbnShahriar, Mas'oodi, and other writers have mentioned about marine capabilities of Karmania. Marine experience from long time rivalry between Mocran and Kerman (Karmania) seamen goes back to Sassanid era. For more detailed account of Karmania (Mocran) maritime stories, please refer to Persian Gulfwritten by Ahmad Eghtedari.

\section{Sassanid Era}

Sassanid Dynasty started by ArdeshirI (Babakan). They kept the rivalry with Rome Emperors that existed during Ashkanid (Parthians). Roman rulers always considered Iran as a barrier to their expansion. Therefore, they sought to engage Iran in long conflicts (Mahmid, 1982, p. 93). Romans engaged Iran in an attempt to conquer Mesopotamiafor an access to Persian Gulf as way of controlling the waterway to India and China. Romans had also tried to conquer Transcaucasia and Mid Asia as a way to gain control of trading land routes.

Sassanid kings had always expressed interest to expand and strengthen their relation with India depending on the political-economic conditions of the time. BahramGur of Sassanid made a trip to India (Mir Khand, V. 1, pp. 360-62). According to IbnJarir al-Tabari, BahramGur took a wife from India - an Indian Princess from Maharaja Adhirajah, Megadha and KanavajiDynasty. DeibelMocranplus parts of territoryalong Send River were her dowry (Tabari, 1889). Rawlinson has rejected Tabari's account of BahramGur marriage to an Indian princess (Rawlinson, 1876). However, Parok has accepted Tabari's account without argument (Parok, 1924).

Deibel is a wealthy port at Send River mouth. Mocran and Send are marine states. The best interpretation from Tabari's account is that Iranians extended their economic control from Mocran to Deibel Port. Maritime activities of Iranians can be confirmed by following events.

Iranian fleet was in competition with Roman fleet as far as Ceylon Port in 512 AD (Hadi Hassan, 1976). AnaccountbyIndicoplostus about GhobadSassani era (487-531 AD) included a story about a tradesman by the name of Sopatrus who traded with Indians and had died thirty five years earlier. Sopatrus had entered Ceylon once at the same time an Iranian ship anchored there. Residents of Adolis went to seaside to welcome the people aboard the Iranian ship. Sopatrus went along the welcoming delegates who behaved with Iranian customs. The local elders and port officials were among the welcoming parties and took visitors to the king (Indicoplostus, V. 11, p. 638). CasmosIndicoplostus wrote his book Christian Historiography in 547 AD. Since, Sopatrus had died 35 years earlier, then, 
the oldest mention of Iranian trading with Ceylon was in 512 AD (Hadi Hassan, 1976).

Khosrua Anooshiravan (531-575 AD) became king in $531 \mathrm{AD}$ and become one prominent Sassanid Dynasty kings. Iranian territory in his era expanded from Lazikaat Black Sea in north to Yemen in south. Anooshiravan's territory extended to Ceylon Island or Serendib according to Tabari, HamzehIsfahani, and Thalebi. Raynaud made a reference to Abul-Feda Geography Book (Al-Boldan Calendar) and concluded in his bookIndia Memoirs that Ceylon was conquered by Iranian fleet (Raynaud, p. 125). Sir James Tenet mentioned the same in his book Ceylon.

Iranians had an outstanding position in the east under Khosrua Anooshiravan rule in early 6th century AD. Iranian ships would make frequent calls to Indian ports. Iranian navy defeated Ceylon in a battle waged in revenge for mistreatment of Iranian tradesmen who lived there (Hadi Hassan, 1976).

Tabari wrote in his history book: "after Yemen came under Kasra rule, he sent one of his commanders with a strong army to conquer Serendib - the land of jewelries governed by India. Iranian commander waged a war against King of Serendib. He took over the Island, killed the king, and took a great wealth of jewelry for Kasra" (Tabari, 1889).

Serendib, Constantinople, and Koor alYamin were among great conquests of Kasra Anooshiravan (HamzehIsfahani, 1967, p. 58). The territory under Anooshiravan ruleextended to Kashmir and Serendib (Thalebi, p. 615). Abul-Feda reported that according to Iranian and Arabic historians Anooshiravan dispatched a fleet of ships to Ceylon in cause of the reported mistreatment of Iranian traders." (Abul-Feda, 1970). All these historical reports point to the fact that Iranians had a strong navy.

Rawlinson has expressed doubt about the reported territory of Anooshiravan. He believed that Anooshiravan never undertook a military expedition to India nor he ever ruled any part of India (Rawlinson, 1876). Contrary to Rawlinson, Hadi Hassan using Indicoplostus as reference wrote that Send River or Phison was the border mark between Iran and India before it entered into Persian Gulf. Indicoplostus wrote that Ceylon Island had a church that provided service to Iranian Christian who had settled there. This church had a priest sent from Iran and a deacon with full accouterment for religious rites. The central location of Ceylon attracted ships from India, Iran, and Abyssinia (Indicoplostus V. 11, p. 337, as quoted by Hadi Hassan, 1976).

Another credible reference about Iranian maritime trading in Indian Ocean is Procopius of Caesarea who was later known as Justinian (527-565 AD). He wrote: "when Helstaius ruled Abyssinia and Assimiphaeus ruled Humerita (a town on Red Sea shores), Emperor Justinian sent a messenger by the name of Julianus to ask both countries to unite with him for a conflict with Iran on the ground of sharing the same religion. Justinian encouraged Abyssinians to enter into silk trade in competition with Iranians. He argued that if Abyssinians bought silk from India and sold to Romans, they would acquire a great wealth. This trade was advantageous to Romans because they did not have to pay their enemy.

On the other hands, Humeritans wanted to appoint Cassius, an escapee, as the chief commander of MadianArmydestined to attack Iran. Madian huge army was made of soldiers from Humeritans and MadianSarasins (the name of a tribe in 
Madian State). Both kings sent back the messenger with promise of assistance. However, none of them kept their promise. It was not possible for Abyssinians to buy silk from Indian as Iranian traders were always present in any ports where Indian ships called. Iranians were resident nearby and would buy the whole cargo in bulk. Humeritans faced another problem. They had to cross a long desert in order to reach the battlefield. Furthermore, they were unwilling to engage in a war with a nation stronger than them (Procopius, V. 1, p. 20, 9, 10, 193, \& 194).

Procopius did not mention any Indian ports of that time, but Indicoplostus mentioned several Indian trading ports from Sassanid era. He wrote: "the most important trading points in India are Sendo, Arhuta (an unknown location on west shores of Gujarat Island) Caliana, Sibur, (Chaul or Chenul, a port South of Mumbai), plus five trading places in Maleh for exporting pepper, namely, Parti, Mangarure (Mangalore), Salopanteh, Nalopaneau, Podupanteau. Also five days far from inland, there is Toprol in Indian Ocean. And after that, Maralo is located inland and serves as a trading center for Shengshels. Next, there is Kabez (presently Kovery), a trading place for Alabandum export. Further away from Tezinesta (China from sea), there is silk producing land of clove." (Indicoplostus, V. 11, p. 337).

South shores of Persian Gulf and Sea of Oman from Basra to Bab el-Mandeb on Red Sea shore were divided into three territories in Sassanid era. Basra Port's ancient name was VahishtAbazArdeshir. The current Basra Port was built during Islamic era. The present Bahrain, Qatar, and Al-Ahsa were a single state called Mishmahig at that time. Omanat region which includes the present United Arab Emirates was part of Yemen. Sassanid
Dynasty controlled this vast region until Islam took over Yemen and Bahrain.

Saudi Arabia and east of Africa were the crossing points for desert going caravans during Parthians. They served as the trading link between Ceylon and ports on Mediterranean Sea. These caravans crossed through shores of Pars Sea. The key role of Pars Sea in this important route brought about many conflicts between Iran and east Roman governments. They all show that Sassanid fleet maintained superiority and controlled the region. Their fleet made frequent calls to ports in Persian Gulf and Sea of Oman. The trading and social relationships established during Sassanid continued during Islamicrulers (IbnMajid, 1923).

Major alluded to thriving marine activities and trading after Parthians Dynasty. He wrote that Iranians gained a better understanding of critical marine trade after Parthians debacle. They learned from Indian traders who frequented Persian Gulf ports that they can reach to Malabar and Ceylon rapidly and safely through sea. Therefore, they built a fleet that would travel to these locations once a year to trade spices and other goods in exchange for Indian valuable goods. They could also buy Chinese goods in Ceylon market.

Iranian traders used this route to ship goods from India to rich residents of Constantinople. They managed to take over the trading that traditionally belonged to Egyptians. Therefore, Egypt trading with other nations gradually subsided and eventually became nil. Iranian trades with India benefited from Iran strategic position. It eventually took complete control of silk trading which traditionally belonged to Ceylon (India in $15^{\text {th }}$ Century, R.H. Major, p. 10).

Linguistic literature provides additional evidences besides historical documents for 
maritime relations between India and Iran. Marine trade was extended during Sassanid era to points beyond Ceylon and stretched to include Sumatra and Chinese ports. Gabriel Frander in his article titled "Iranian Elements in Arabic Maritime Texts" published in Asiatic Journal proves the point by referring to Persian words. He writes: "the role of Arabs in establishing and development of maritime relations between Persian Gulf ports and Far East has been exaggerated. Most likely, Arabs simply followed the route established earlier by Iranians.

The word "Nakhoda" or "Nookhoda" in Arabic language is taken from Iranians and is written the same way as Iranians spelling. The word Baghboor as mentioned by IbnKhordadbeh or the word Faghfoor as mentioned by Mas'udi and AbulFida are used as pseudonym for Chinese Emperor. These words in Arabic Language were taken from Persian word Baghpoor meaning son of God. The Persian word was a translation of Chinese word Tin Tisumeaning son of sky (Frander, pp. 193275: April and June, 1924, as quoted by Hadi Hassan, 1976). He mentioned several Farsi words that were used in India such as Bijat (islands in Indian Ocean), Khoshnami (a mountain in Andaman Archipelago), Sandar, Foolat, Darchin (Chinese Wood), JozBoau (hazelnut), and Jozolhend (coconut).

One influence taken from India is the game of Chess during Sassanid era. Iranians adapted this game from India which later became a national game. Another example is CalilehvaDemneh (Calila e Dimna) tales which was translated into Pahlavi Language. The Arabic version was translated from Pahlavi and became one of classic Arabic literary works (Illiff, 1953). All these cultural exchanges were not possible without extended relationships between Iran and
Indian Subcontinents, particularly supported by marine trading through Pars Sea.

\section{Conclusion}

Pars Sea is geographically and historically one of the key strategic seas on earth. It plays a key political-economic role in the region. Several powerful governments were formed in Pars Sea region throughout history, especially during preIslamic period. These governments had vast areas under their rules. They maintained long political-economic relations with their neighboring and faraway countries. Indian Subcontinent is one of the oldest countries with marine relations with Iran according to historical documents. The earliest marine relations with India started from Median Empire and lasted throughout Sassanid Dynasty. Pars Sea was a connecting medium for political-economic relations. The historical relation continued throughout the history in spite of numerous problems. This paper presented some of the evidences for the historical relationship. There is no doubt that Pars Sea has played a more extensive role than is evident from the historical literature. Because of limited available documents, this paper relied only on what was accessible. Hope this paper can serve as an evidence to confirm the hypothesis that silk waterway connected east to west Asia through Pars Sea with further connection to Europe by way of Tigris and Euphrates Rivers.

\section{References}

Abul-Feda (1970). Al-Boldan Calendar, (A. H. Ayati, Trans), Tehran: Iranian Culture Foundation.

Afshar, A. (1985). Tribute to Dr. Mahmoud AfsharYazdi, V. 2, Tehran: Mahmoud AfsharYazdi Endowment Office. 
Diaconoff, M.M. (1972). The Parthians, (K. Keshavarz, Trans), $2^{\text {nd }}$ Edition, Tehran: Payam.

Durant, W. (1986). History of Eastern Civilization: The Sit of Civilization, (A. Aram, et al, Trans), V. 1, Tehran: Islamic Revolution Training and Publishing Organization.

Eghtedari, A. (1965). Persian Gulf, Tehran: Ebn-e Sina.

Frander, G. (1924). Iranian Elements in Arab Maritime Texts, Asiatic Journal, April and June.

Gutschmidt, A. (1965). History of Iran and Its Neighboring Countries from Alexander to Parthian's Debacle, (K. Jahandari, Trans), Tehran: Ali Akbar Elmi.

Hadi Hassan, (1976). History of Iranian Maritime, (G. Aghasi, Trans), Tehran: Aria National Shipping.

Hamawi, Y. (1966). Mojam al-Baldon (AlBoldan Calendar), (Westenfeld Editor), V. 4, Tehran: Asadi.

Hamidi, S.J. (1990). Sa'di in Kish Island, Kish Quarterly, 1 (1).

HamzehIsfahani, H.H. (1848). History of Prophets and Kings (HamzehIsfahani History), (Gottwald Editor), Saint Petersburg and Leipzig.

HamzehIsfahani, H.H. (1967). History of Prophets and Kings, (J. Sho'ar, Trans), Tehran: Iranian Culture Foundation.

Hoorani, J. (1969). Arab Maritime in Indian Ocean, (M. Moghadam, Trans), Tehran: Ibn-e Sina.

IbnMajed, Sh., A. (1923). Principles and Rules of Marine Scienceand Their Benefits, (G. Frander, Editor), Paris.
Illiff, J.H. (1953). Persia and the Ancient World, (A.J. Arberi, Editor, A. Hatami, Trans), Iran Heritage.

Indicoplostus, C. Christian Historiography, English Translation, V. 11.

Mahmid, M.A. (1982). Research in Political History of Iran, Tehran: Mitra.

Mashkoor, M.J. (1976). History of Iran Cultural Relations before Islam: History of Iran Cultural Relations, V. 1, Tehran.

Mimir, E., Encyclopedia of Britannica: Persians, V. 2.

Mirkhand, M.K., Roze al-Safa, (F.F. Arbutnat, Editor, Ratesk, E., Trans), V. 1, London: Royal Asian Society of England.

Mosaheb, G. (1966). Farsi Encyclopedia, V. 1, Tehran: Franklin Institute

Nehru, J.L. (1977). Discovering India, (M. Tafazoli, Trans), Tehran: Amir Kabir Publishing.

Parok, M.J. (1924). Sassanid Coins, $2^{\text {nd }}$ Edition, Mumbai.

Pripolus (1927). Eritrea Sea, (H. Frisk Editor), Germany: Gothenburg.

Procopius, Beautiful Pars, (J. B. Dowing, Trans), V. 1.

Rawlinson, J. (1876). Seventh Great Oriental Monarchy, London.

Strabon (1866). Strabon Geography: About India and Pars, (Tardio Editor), V. 15, Paris.

Tabari, M.J. (1889). The History of Prophets and Kings (Tabari History), (Dakhvieh Editor), V. 1, London. 
Tabari, M.J. (1960). Al-Tabari History (The History of Prophets and Kings), (Dakhvieh Editor), V. 2, Cairo: Dar al-Ma'ref.

Tabari, M.J. (1973). Al-Tabari History or The History of Prophets and Kings, (A. Payandeh, Trans), Tehran: Iranian Culture Foundation.
Thalebi, History of Pars Kings, (Rotenberg, Editor).

Willerus, Z.I.M., Iran and India before Islam, in Pigat, The Ancient India, V. 4.

Wilson, S.A. (1969). Persian Gulf, (M. Sa'idi, Trans), Tehran: Bongah-e TarjomehvaNashrKetab.

How to cite this article: Ali Ahmadalizadeh, Nader Karimian Sardashti, Pars Sea: Maritime Connection between Iran and Indian Subcontinent. International Journal of Advanced Studies in Humanities and Social Science, 2018, 7(4), 426-436. http://www.ijashssjournal.com/article_84104.html 